\title{
Shared Anti-Idiotype-AB-S005
}

National Cancer Institute

\section{Source}

National Cancer Institute. Shared Anti-Idiotype-AB-S005. NCI Thesaurus. Code C29423.

A monoclonal antibody directed against a specific tumor-associated antigen (TAA).

$(\mathrm{NCl04})$ 